\title{
Phytochemical Profile and Antioxidant Activity of Propolis Ethanolic Extract from Tetragonula Bee
}

\author{
Diah Kartika Pratami ' ${ }^{1}$ Abdul Mun'im ${ }^{2}$, Andini Sundowo ${ }^{3}$, Muhamad Sahlan ${ }^{4,5 *}$
}

\section{Diah Kartika Pratami ${ }^{1}$, Abdul Mun'im², Andini Sundowo ${ }^{3}$, Muhamad Sahlan ${ }^{4,5 *}$ \\ ${ }^{1}$ Faculty of Pharmacy, Universitas Indo- nesia, INDONESIA. \\ ${ }^{2}$ Department of Pharmacognosy- Phytochemistry, Faculty of Pharmacy, Universitas Indonesia, INDONESIA. ${ }^{3}$ Natural Product and Pharmaceutical Chemistry Research Group, Indonesian Institute of Sciences, INDONESIA. \\ ${ }^{4}$ Faculty of Engineering, Universitas Indonesia, INDONESIA. \\ ${ }^{5}$ Research Center for Biomedical Engineering, Universitas Indonesia, INDONESIA.}

\section{Correspondence}

Muhamad Sahlan

Research Center for Biomedical Engineering, Faculty of Engineering, Universitas Indonesia, Kampus UI Depok, 16424, West Java, INDONESIA.

Phone No: +62-21-7863516

Fax +62-21-7863515

E-mail: sahlan@che.ui.ac.id

History

- Submission Date: 04-10-2017.

- Review completed: 08-11-2017;

- Accepted Date: 20-11-2017

DOI : 10.5530/pj.2018.1.23

Article Available online

http://www.phcogj.com/v10/i1

Copyright

(C) 2018 Phcog.Net. This is an openaccess article distributed under the terms of the Creative Commons Attribution 4.0 International license.

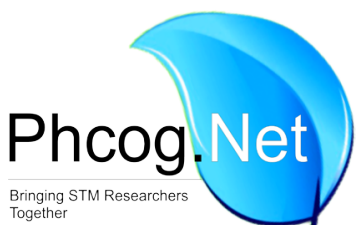

\begin{abstract}
Objective: This research aimed to determine the phytochemical composition and the antioxidant properties in vitro of three types propolis collected from the region of South Sulawesi Province of Indonesia. Methods: Samples from three types of propolis: smooth, rough and mix were extracted with $96 \%$ ethanol. The propolis ethanolic extracts (PEE) was dried and studied their antioxidant properties by using FRAP (Ferric Reducing Antioxidant Power) and DPPH radical scavenging assays. Total phenolic compounds were quantified by Folin-Ciocalteu, and total flavonoid contents were also quantitatively determined by the $\mathrm{AlCl}_{3}$ colorimetric method with a microplate reader. The chemical compounds were identified by an ultraperformance liquid chromatography TOF mass spectrometer (UPLC-TOF-MS) using the MSE mode. Results: The sequence of potential antioxidant activity of PEE is smooth propolis $>$ mix propolis $>$ rough propolis. Which showed by $\mathrm{EC}_{50}$ value with $\mathrm{DPPH}$ assays are $25.54 ; 31.66$; and 69.96 $\mu \mathrm{g} / \mathrm{mL}$, respectively and also showed by $\mathrm{EC}_{50}$ value with FRAP assays consecutively were $26.41 ; 32.10$; and $34.62 \mu \mathrm{g} / \mathrm{mL}$. Smooth propolis has the lowest $E_{50}$ value of all the types of propolis examined, contains total flavonoid content $791.06+13.06 \mathrm{mg} \mathrm{QE} / \mathrm{g}$ extract and total phenolics content $426.91+61.08 \mathrm{mg} \mathrm{GAE} \cdot \mathrm{g}^{-1}$ extract. Chemical component identified by UPLC-TOF-MS using the MSE mode were (-)-Sesamin $\mathrm{C}_{20} \mathrm{H}_{18} \mathrm{O}_{6}$; Curcumin $\mathrm{C}_{21} \mathrm{H}_{20} \mathrm{O}_{6}$; 8-epiHelenalin $\mathrm{C}_{15} \mathrm{H}_{18} \mathrm{O}_{4}$; and Kushenol $\mathrm{F} \mathrm{C}_{25} \mathrm{H}_{28} \mathrm{O}_{6}$. Conclusion: Smooth propolis which taken from inside the nest was the most potent antioxidant among of all the types of examined propolis. The antioxidant activity was influenced by the phenolic content of Propolis.
\end{abstract}

Key words: DPPH, FRAP, TPC, TFC, Microplate method, UPLC-TOF-MS.

\section{INTRODUCTION}

Bees produce propolis, a mixture of bee saliva and gum produced by leaf buds and stems, which come out through plant's skin collected by bees. ${ }^{1}$ The physical properties of raw propolis are hard and wax-like when fresh, but soft and very sticky when warm. It has a characteristic aromatic smell and odor; its range color varies from light to dark brown, red, yellow, or green, depending on its age and source. ${ }^{2}$ Chemical composition, which bees collect from the resinous plant parts, may influence its biological effect. ${ }^{3}$ The composition of propolis depends on diverse vegetation, phytogeographic region, and time of the collection. ${ }^{4}$

Results from previous researchers found more than 300 components contained in propolis i.e. aromatic acids; aromatics esters; flavanones; flavones and flavonol; chalcones and dihydrochalcones; terpenoids; acyclic hydrocarbons and esters; alcohols; aliphatic acids (short-chain); aliphatic esters; aliphatic fatty acids (long-chain) and esters; amino acids; aromatic hydrocarbons; acetophenones and other ketones; glycerol derivatives; steroids; sugars and sugar alcohols; and miscellaneous ingredients. ${ }^{2}$ The quantification of the phytochemical content of propolis can be determined throught total flavonoid and total phenolics content. These parameters are related to the biological activity. ${ }^{5}$ All species stingless bees (Hymenoptera: Apidae) produce propolis in this study belong to the genus Tetragonula, Tetragonula fusco balteata; T. laeviceps; T. biroi; T. sapiens. ${ }^{6}$ The genus is small body size. Tetragonula spp is one species of bees producing propolis honey more than other bee species.?

Propolis contained one of the biological activity was well known as an antioxidant. Propolis showed the most potent antioxidant of all the bee products including honey, royal jelly, and bee pollen. ${ }^{8}$ Antioxidant activity of propolis was originated from their polyphenolic substances. The use of propolis with antioxidant capacity for prevention and treatment of diseases related to the increase of oxidative stress such as cancer, aging, and cardiovascular diseases. ${ }^{4}$

This research aimed to determine the phytochemical composition and the antioxidant properties in vitro of three types propolis collected from the region of South Sulawesi Province of Indonesia.

Cite this article: Pratami DK, Mun'im A, Sahlan M, Sundowo A. Phytochemical Profile and Antioxidant Activity of Propolis Ethanolic Extract from Tetragonula Bee. Pharmacog J. 2018;10(1):12835 . 


\section{MATERIALS AND METHODS}

\section{Samples}

Tetragonula Beehives were taken from Masamba, North of Luwu district, South Sulawesi Province of Indonesia. The types of beehive were smooth (taken from inside the nest), rough (taken from outside the hive) and mix (a combination of both).

\section{Chemicals}

Quercetin, 2,2-Diphenyl- 1-picrylhydrazyl (DPPH), Foline-Ciocalteu, ferric chloride,2,4,6-Tri(2-pyridyl)-s-triazine(TPTZ), acetic acid (glacial) anhydrous, $\mathrm{AlCl}_{3}$ anhydrous and sodium carbonate were purchased from Sigma Chemical Company (Sigma Aldrich, Singapore). Gallic acid and ethanol were obtained from Merck (Darmstadt, Germany).

\section{Preparation of Propolis Extracts}

PEE was extracted by Muhamad Sahlan method (2013). ${ }^{9}$ The beehive sample $(1 \mathrm{~kg})$, from three types of propolis: smooth, rough and mix, were macerated with $5 \mathrm{~L}$ of $96 \%$ ethanol, allowed to stand for $16 \mathrm{~h}$. After that, filtrate and residue were separated by filtration. The water was added to extract until $70 \%$ ethanol-water v/v and incubated on water bath $50^{\circ} \mathrm{C}$ for 30 mins, to separate propolis with wax. Then, the solution was frozen in the refrigerator overnight. Propolis separated with wax apparently at room temperature incubation; separate the wax and propolis by filtration. The filtrate was evaporated using rotary vacuum evaporator (Rotavapor R-205, Büchi, Switzerland) to give a viscous residue and then was dried using oven vacuum. We obtained the dried propolis ethanolic extracts and wax free.

\section{Determination of Percentage Yield (\%)}

The percentage of yield was determined using the dry weight of extract (a) and soaked samples material (b) using Equation 1,

$$
\text { Percentage Yield }(\%)=\frac{a}{b} \times 100
$$

The extraction yield was calculated for each type of PEE in triplicate.

\section{Phytochemical Screening}

The qualitative phytochemistry test was conducted as shown in Table 1 according to Indonesian Materia Medika $(1995)^{10}$ and Harborne (1998). ${ }^{11}$

\section{Determination of Total Phenolic Content}

TPC method was based on the microplate method given by Ahmad et al (2017) ${ }^{12}$ with some modifications. A total of $25 \mu \mathrm{L}$ of the sample solution or the standard solution was mixed with $100 \mu \mathrm{L}$ of $1: 4$ diluted Folin-Ciocalteu reagent and shaken for $60 \mathrm{~s}$ in a 96-well microplate and incubated for $4 \mathrm{~min}$. Then add the mixture with $75 \mu \mathrm{L}$ of sodium carbonate solution $\left(100 \mathrm{~g} \mathrm{~L}^{-1}\right)$, and shaken for 60 s. Incubate it two $\mathrm{h}$ at room temperature. The absorbance was measured at $\lambda 765 \mathrm{~nm}$ using a microplate reader 96 well $^{\text {su }}$ (Versa Max ELISA Microplate Reader, USA).

Gallic acid solution (5-300 $\mathrm{mgL}^{-1}$ ) was used as standards. The calibration curve of standards (gallic acid) was measured by the absorbance from microplate reader instrument and was calculated using SoftMax 6.5.1 software. The equation formula was $\mathrm{Y}=0.0633 \mathrm{x}+0.0099$ and $\mathrm{R}^{2}=0.9947$, where $\mathrm{Y}$ is the yield of GAE (total phenolic content) and $\mathrm{X}$ is the absorbance of gallic acid or samples. All determinations were carried out in triplicate.

\section{Determination of Total Flavonoid Content}

TFC was determined by the $\mathrm{AlCl}_{3}$ microplate method given by Massoumeh Farasat $(2014)^{13}$ with some modification. A total of $20 \mu \mathrm{L}$ of each sample or standard solution were mixed with $20 \mu \mathrm{L}$ of $10 \% \mathrm{AlCl}_{3}$,
$20 \mu \mathrm{L}$ of $\mathrm{CH}_{3} \mathrm{COOK}(1 \mathrm{M})$ and $140 \mu \mathrm{L}$ of distilled water, and shaken for $60 \mathrm{~s}$. Incubate it $30 \mathrm{~min}$ at room temperature. The absorbance of was measured at $\lambda 415 \mathrm{~nm}$ using the microplate reader96 well ${ }^{\text {rs }}$ (Versa Max ELISA Microplate Reader, USA).

Quercetin ethanolic solution $\left(5-200 \mathrm{mgL}^{-1}\right)$ was used as standards. The calibration curve of standards (quercetin) was measured by the absorbance from microplate reader instrument and was calculated using SoftMax 6.5.1 software. The equation formula was $y=0.0366 x-0.0146$ and $\mathrm{R}^{2}=0.998$, where $\mathrm{Y}$ is the yield of $\mathrm{QE}$ (total flavonoid content) and $\mathrm{X}$ is the absorbance of quercetin or samples. All determinations were carried out in triplicate.

\section{Measurement of Antioxidant Activity with DPPH Assay}

The microplate antioxidant activity with DPPH assay was based on the method described by Bobo Garcia $(2015)^{14}$ with some modifications. DPPH method procedure of antioxidant activity assay is in Table 2. The absorbance was recorded using a microplate reader 96 well $^{\text {ma }}$ (Versa Max ELISA Microplate Reader, USA). The \% DPPH quenched was calculated using Equation 2,

$$
\% \text { DPPH quenched }=\left[1-\left(\frac{\text { A sample }- \text { A blank }}{\text { A control }- \text { A blank }}\right)\right] \times 100
$$

The concentration of samples resulting in 50\% inhibition on DPPH was calculated, expressed as anEC ${ }_{50}$ value $(\mu \mathrm{g} / \mathrm{ml})$, and obtained by using SoftMax Pro6.5.1 software. All determinations were carried out in triplicate.

\section{Measurement of Antioxidant Activity with FRAP Assay}

The microplate FRAP assay was based on the method described by Bolanos De La Torre (2014) $)^{15}$ and Shinta Marlin (2017) ${ }^{16}$ with some modifications. The FRAP reagent solution contains 10:1:1 of acetate buffer (300 mM, pH 3.6), TPTZ (40 mM dissolved with $40 \mathrm{mM} \mathrm{HCl}$ ) and ferric chloride ( $20 \mathrm{mM}$ in water). The procedure of FRAP method assay is in Table 3. The absorbance was measured at $\lambda 595 \mathrm{~nm}$ using a microplate reader (VersaMax; Molecular Devices, USA). The percentage of reducing power capacity can be calculated using the Equation 3,

$$
\% \text { Capacity }=(1-\mathrm{Ts}) \times 100 \%
$$

Ts $=$ Transmittan

As $=-\log \mathrm{Ts}$

As $=$ As positive control - As blank FRAP solution

The result was expressed as $\mathrm{EC}_{50}(\mu \mathrm{g} / \mathrm{ml})$, calculated using the equation of nonlinear regression by Microsoft Office Excel and SoftMax Pro6.5.1 software. $\mathrm{EC}_{50}$. The analysis was done in triplicate.

\section{HPLC-ESI-MS/MS Analysis}

The analytical LC-MS/MS experiments were performed using ACQUITY UPLC I-Class System connected through a split to the mass spectrometer the Xevo G2-XS Q-tof Mass Spectrometer (Waters, USA) in Research Centre for Chemistry, Indonesian Institute of Science. The column temperature was set at $40^{\circ} \mathrm{C}$. The flow rate was $0.30 \mathrm{~mL} / \mathrm{min}$. The HPLC analyses were performed using a linear gradient solvent system consisting of A: B $\left(0.1 \%\right.$ formic acid in $\mathrm{H}_{2} \mathrm{O}: 0.1 \%$ formic acid in methanol) as follows: $\mathrm{t}=0 \min 95 \% \mathrm{~A} ; \mathrm{t}=3 \min 75 \% \mathrm{~A} ; \mathrm{t}=7 \min 40 \% \mathrm{~A} ; \mathrm{t}=10 \mathrm{~min}$ $20 \% \mathrm{~A} ; \mathrm{t}=13 \mathrm{~min} 100 \% \mathrm{~B} ; \mathrm{t}=15 \mathrm{~min} 5 \% \mathrm{~B}$. The injection volume was $1 \mu \mathrm{L}$. The total run time was $15 \mathrm{~min}$. Sample manager temperature was $20^{\circ} \mathrm{C}$. Wash solvent was ACN: IPA: $\mathrm{Me} \mathrm{OH}: \mathrm{H}_{2} \mathrm{O}$ (1:1:1:1). Wash solvent pre inject $10 \% \mathrm{MeOH}$ in $\mathrm{H}_{2} \mathrm{O}$. Data acquisition was using $\mathrm{MS}^{\mathrm{E}}$ function ESI ionization type under positive electrospray. Acquisition range was $100-1200 \mathrm{~m} / z$. Capillary and cone voltage was $0.8 \mathrm{kV}$. and $30 \mathrm{~V}$, respectively. 
The source temperature was at $120^{\circ} \mathrm{C}$, desolation gas flow was $1000 \mathrm{~L} /$ $\mathrm{hr}$, and cone gas flow $50 \mathrm{~L} / \mathrm{hr}$. Scan times was $0.250 \mathrm{~s}$. Data acquisition and data processing use $\mathrm{UNIFI}^{\oplus}$ Software.

\section{RESULTS}

\section{Determination of Percentage Yield (\%)}

The extractant from three samples of rough propolis, smooth propolis, and mix propolis, then process using rotary evaporator and oven vacuum to get dry extract and wax free of propolis ethanolic extracts. As can be seen in Table 5 obtained highest yield at Mix Propolis Ethanolic Extract (MPEE), PEE from mix propolis, equal to $20.21 \%$ with the content of propolis dry matter in PEE equal to $40.33 \mathrm{mg} / \mathrm{mL}$.

\section{Phytochemical Screening}

Phytochemical screening of PEE showed the presence of alkaloids, flavonoids, phenolics, glycosides, tannins, terpenes and saponins and negative to anthraquinone. Here is the test results data shown in Table 4.

\section{Determination of Total Phenolic and Flavonoid Content}

The TPC and TFC from three types of ethanolic extract propolis as shown in Figure 1. The yields of total phenolic content from smooth, rough and mix propolis were $426.91 \pm 61.08 \mathrm{mg} \mathrm{GAE} / \mathrm{g}$ extract; $269.57 \pm$ $20.37 \mathrm{mg} \mathrm{GAE} / \mathrm{g}$ extract; and $319.51 \pm 6.37 \mathrm{mg} \mathrm{GAE} / \mathrm{g}$ extract.

Table 1: Phytochemical Screening of Propolis Ethanolic Extract.

\begin{tabular}{cc}
\hline $\begin{array}{c}\text { Phytochemical } \\
\text { Contents }\end{array}$ & Methods \\
\hline Alkaloid & Mayer, Dragendorff, and Bouchardat reagents \\
Flavonoid & Shinoda and Wilson Toubock reaction \\
Phenolics & Folin-Ciocalteu method \\
Terpenoid & Liebermann- Burchard reagent \\
Tannin & Gelatin test, Gelatin-salt test, ferrous (III) chloride test \\
Glycoside & Molisch reaction \\
Anthraquinone & Borntrager reaction \\
\hline
\end{tabular}

Table 2: Composition of the solution to test the antioxidant activity with DPPH methods.

\begin{tabular}{cccc}
\hline \multirow{2}{*}{ Material } & \multicolumn{3}{c}{ Volume $(\mu \mathrm{L})$} \\
\cline { 2 - 4 } & Blank & Control & Sample \\
\hline Gallic acid / PEE & - & - & 20 \\
DPPH 150 $\mu$ mol/L & - & 180 & 180 \\
Ethanol p.a & 200 & 20 & - \\
\hline
\end{tabular}

were shaken for 60 seconds and incubated for 40 minutes in the dark and measured absorbance at $\lambda 516 \mathrm{~nm}$
Based on the measurement results, the yields of total flavonoid content from smooth, rough and mix propolis were $791.06 \pm 13.06 \mathrm{mg} \mathrm{QE} / \mathrm{g}$ extract; $324.43 \pm 11.84 \mathrm{mg} \mathrm{QE} / g$ extract; and $530.86 \pm 31.43 \mathrm{mg} \mathrm{QE} / \mathrm{g}$ extract.

\section{Measurement of Antioxidant Activity}

The antioxidant activity test was performed using DPPH and FRAP assay. Antioxidant capacity was expressed as $\mathrm{EC}_{50}(\mu \mathrm{g} / \mathrm{mL})$ of DPPH scavenging activity and FRAP capacity. The following results are obtained as shown in Table 5. The best antioxidant activity using DPPH method was smooth propolis ethanolic extract (SPEE), PEE from smooth propolis, with the $\mathrm{EC}_{50}$ value of $25.53 \mu \mathrm{g} / \mathrm{mL}$. The DPPH scavenging activity of the PEE in descending order of potency was gallic acid $>$ smooth propolis $>$ mix propolis $>$ rough propolis.

From the experiments, SPEE also showed the best reducing power capacity with the $\mathrm{EC}_{50}$ value of $26.41 \mu \mathrm{g} / \mathrm{mL}$. The descending order of the FRAP reducing power of the PEE was gallic acid $>$ smooth propolis $>$ mix propolis $>$ rough propolis.

Table 3: Composition of the solution to test the antioxidant activity with FRAP methods.

\begin{tabular}{cccc} 
& \multicolumn{3}{c}{ Volume $(\mu \mathrm{L})$} \\
\cline { 2 - 4 } Material & Blank & $\begin{array}{c}\text { Control } \\
\text { Blank }\end{array}$ & $\begin{array}{c}\text { Positive Control / } \\
\text { Sample }\end{array}$ \\
\hline FRAP reagent solution & - & 270 & 270 \\
Gallic acid / PEE & - & - & 30 \\
Ethanol p.a & 300 & 30 & - \\
\hline
\end{tabular}

were incubated for 30 minutes at a temperature of $37^{\circ} \mathrm{C}$ and measured absorbance at $\lambda 595 \mathrm{~nm}$

Table 4. Phytochemical Screening of Propolis Ethanolic Extract

\begin{tabular}{cccc}
\hline Phytochemical Contents & $\begin{array}{c}\text { Smooth } \\
\text { Propolis }\end{array}$ & $\begin{array}{c}\text { Rough } \\
\text { Propolis }\end{array}$ & Mix Propolis \\
\hline Alkaloid & + & + & + \\
Flavonoid & + & + & + \\
Phenolics & + & + & + \\
Terpenoid & + & + & + \\
Tanin & + & + & + \\
Glycoside & + & + & + \\
Anthraquinone & - & - & -
\end{tabular}

Note. + : detected, - : No detected

Table 5: Extraction yield, content of phenolics and flavonoids, and antioxidant activity of PEE.

\begin{tabular}{|c|c|c|c|c|c|c|}
\hline \multirow{2}{*}{$\begin{array}{l}\text { Sample } \\
\text { Name }\end{array}$} & \multirow{2}{*}{$\begin{array}{l}\text { Extraction yields } \\
\qquad(\% \mathrm{w} / \mathrm{w})\end{array}$} & \multirow{2}{*}{$\begin{array}{l}\text { Dry matter in PEE } \\
\qquad(\mathrm{mg} / \mathrm{mL})\end{array}$} & TPC & TFC & \multirow{2}{*}{$\begin{array}{c}\mathrm{EC}_{50} \mathrm{DPPH} \\
\text { Inhibition } \\
(\mu \mathrm{g} / \mathrm{mL})\end{array}$} & \multirow{2}{*}{$\begin{array}{c}\mathrm{EC}_{50} \text { FRAP } \\
\text { Capacity }(\mu \mathrm{g} / \\
\mathrm{mL})\end{array}$} \\
\hline & & & (mg GAE/g) & (mg QE/g) & & \\
\hline SPEE & $17.06+0.23$ & $36.07+0.77$ & $426.91+61.08$ & $791.06+13.06$ & 25.53 & 26.41 \\
\hline RPEE & $18.03+0.38$ & $34.12+0.45$ & $269.57+20.37$ & $324.43+11.84$ & 31.66 & 34.62 \\
\hline MPEE & $20.21+0.14$ & $40.43+0.27$ & $319.51+6.37$ & $530.86+31.43$ & 69.96 & 32.1 \\
\hline
\end{tabular}

Note: SPEE, Smooth Propolis; RPEE, Rough Propolis; MPEE, Propolis Mix; TP, total phenolics content; GAE, gallic acid equivalents; TF, total flavonoids content; QE, quercetin equivalents; DPPH, 2,2-Diphenyl-1-picrylhydrazyl; $\mathrm{EC}_{50}$, Effective Concentration $50 \%$ antioxidant capacity; FRAP, ferric reducing antioxidant power. Data shown in the table are expressed as mean \pm standard deviation $(=3)$. 
A clear picture in Figure 2-5 is obtained when the TPC, TFC and antioxidant assays are compared. From Figure 2-3, It was found that TPC and TFC with $\mathrm{EC}_{50}$ values for DPPH had weak correlation $\left(\mathrm{r}^{2}=0.6776\right.$ and $\mathrm{r}^{2}$ $=0.8009$, respectively). Then from Figure $4-5$, It was found that TPC and TFC with $\mathrm{EC}_{50}$ values for FRAP had high correlation $\left(\mathrm{r}^{2}=0.9999\right.$ and $r^{2}=0.9769$, respectively).

\section{HPLC-ESI-MS/MS Analysis}

The composition of a propolis ethanolic extract of Tetragonula $s p$ was examined on Aquity UPLC and the LC-MS/MS chromatogram was shown in Figure 6-7. Tentative identification of phytochemicals in smooth propolis extract and rough propolis extract were presented in Table 6 and 7, respectively. As shown in Figure 6-7, a total of various compounds were identified by comparing molecular weight $(\mathrm{M})$, and $\mathrm{m} / \mathrm{z}$ fragment with the UNIFI literature data and the results were shown in Table 6-7.

\section{DISCUSSION}

The yields of propolis extract from this study seen in Table 5 are lower than extraction of Bolivian Propolis that obtained by Nélida Nina (2016) ${ }^{17}$ ranged from 45.76 to $59.68 \% \mathrm{w} / \mathrm{w}$ and yield of propolis T. incisa, T. fuscibisca and T. fuscobalteata maceration use methanol described by
Paula M. Kustiawan (2014). ${ }^{18}$ But it yields is higher than the extraction conducted by Hasan, A. E.Z (2014). ${ }^{19}$ He obtained from five regions in Indonesia were different, yields of propolis from Makassar $1.85 \pm 0.51 \%$ w/w, Pekanbaru 19.97 \pm 2.19 (\%) w/w, Kendal 7.28 $\pm 1.59 \%$ w/w, Pandeglang $11.05 \pm 3.20 \% \mathrm{w} / \mathrm{w}$, and Banjarmasin $8.38 \pm 0.70 \% \mathrm{w} / \mathrm{w}$.

The propolis extraction that modified by Sahlan et al. ${ }^{9}$ suitable used for propolis that is not heat resistant. In this research, the solvent used is ethanol $96 \%$, which is semi-polar so that the active compounds with the different polarity is expected to be extracted perfectly. The active compounds are obtained while doing the stirring (mixing) a lot faster. Ethanol as organic solvents is commonly used than methanol in the pharmaceutical industry as reaction media in natural products extraction and for cleaning of equipment.

The content of phenolic and flavonoid compounds in the different extracts obtained from Propolis Tetragonula spp in Table 5 shows that SPEE, smooth propolis, presented the highest TPC $426.91 \pm 61.08 \mathrm{mg}$ GAE/g extract and TFC 791.06 $\pm 13.06 \mathrm{mg}$ QE/g extract.

The results of TPC are superior to Algerian Propolis those reported by Zina Mouhoubi Tafinine $(2016)^{20}$ ranged from 1.71 to $53.51 \mathrm{mg}$ GAE $\mathrm{g}^{-1}$, Chinese Propolis those reported by Kai Wang $(2014)^{21}$ ranged from $145.54+75.89$ to $233.98+70.84 \mathrm{mg}$ GAE g-1, Bolivian Propolis those

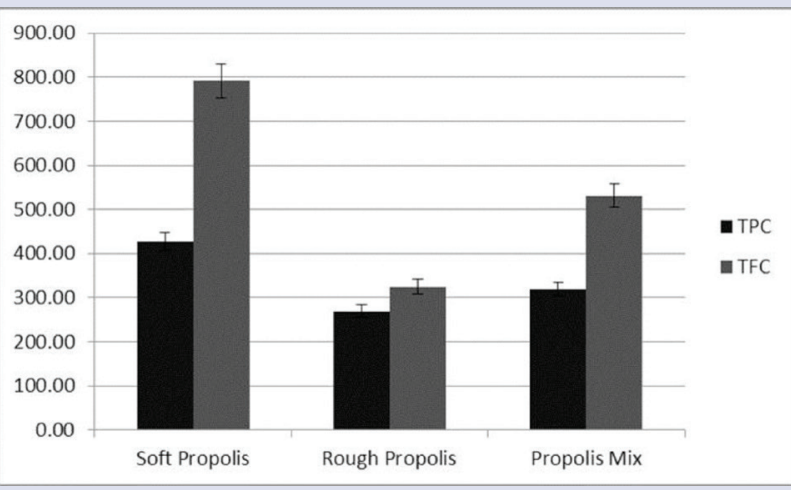

Figure 1: Total phenolic and flavonoid content from propolis ethanolic extract.

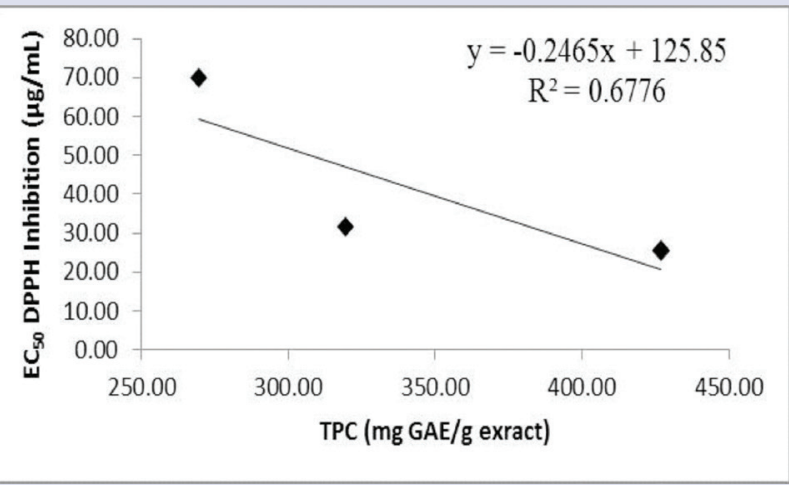

Figure 2: Regression Equation between TPC and Antioxidant Activity by DPPH assay.

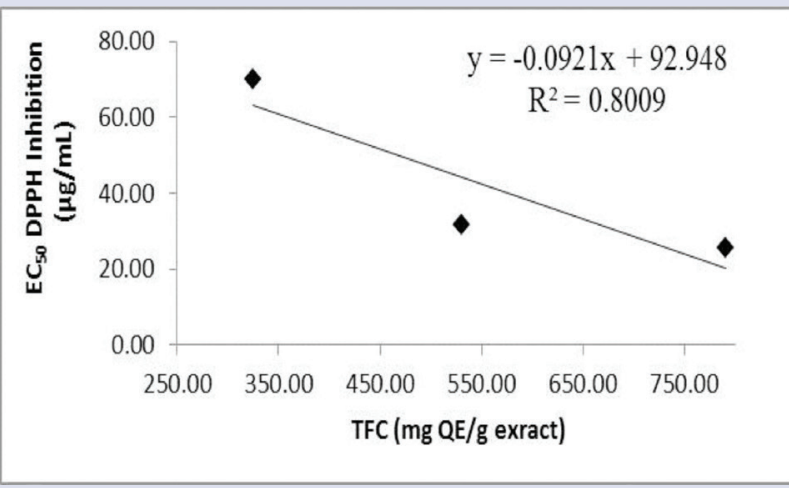

Figure 3: Regression Equation between TFC and Antioxidant Activity by DPPH assay.

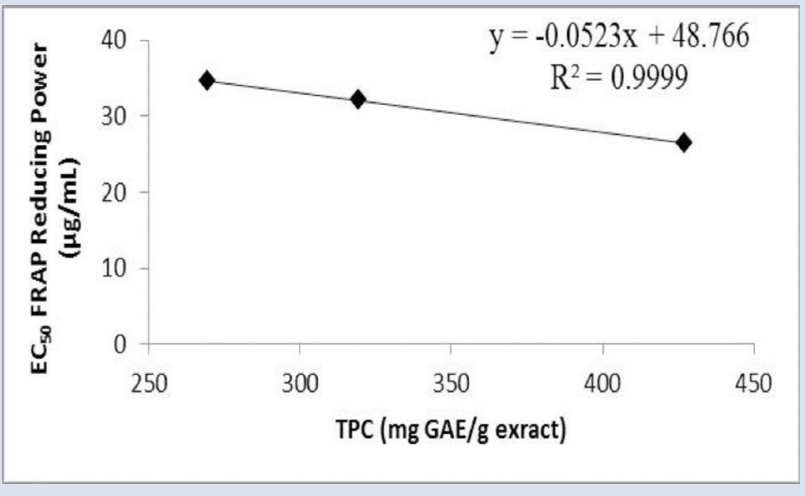

Figure 4: Regression Equation between TPC and antioxidant capacity by FRAP assay. 
Pratami et al.: Phytochemical Profile and Antioxidant Activity of PEE

Table 6: Identification of chemical compounds in smooth propolis by HPLC-ESI-MS/MS data.

\begin{tabular}{cccccc}
\hline No & $\begin{array}{c}\text { Tentative Component } \\
\text { Identification }\end{array}$ & Observed $\mathbf{m} / \mathbf{z}$ & $\begin{array}{c}\text { Observed RT } \\
(\mathbf{m i n})\end{array}$ & m/z Fragment & Formula \\
\hline 1 & Kushenol-F & 425.1952 & 9.87 & 257,42 & $\mathrm{C}_{25} \mathrm{H}_{28} \mathrm{O}_{6}$ \\
2 & 8-epi-Helenalin & 263.1279 & 10.04 & 263,507 & $\mathrm{C}_{15} \mathrm{H}_{18} \mathrm{O}_{4}$ \\
3 & $(-)$-Sesamin & 355.1172 & 10.76 & 355,487 & $\mathrm{C}_{20} \mathrm{H}_{18} \mathrm{O}_{6}$ \\
4 & $(-)$-Sesamin & 377.0989 & 10.76 & 355,453 & $\mathrm{C}_{20} \mathrm{H}_{18} \mathrm{O}_{6}$ \\
5 & Curcumin & 369.1328 & 11.04 & 299,369 & $\mathrm{C}_{21} \mathrm{H}_{20} \mathrm{O}_{6}$ \\
\hline
\end{tabular}

Table 7: Identification of chemical compounds in rough propolis by HPLC-ESI-MS/MS data.

\begin{tabular}{cccccc}
\hline No & $\begin{array}{c}\text { Tentative Component } \\
\text { Identification }\end{array}$ & Observed $\mathbf{m} / \mathbf{z}$ & $\begin{array}{c}\text { Observed RT } \\
(\mathbf{m i n})\end{array}$ & $\mathbf{m} / \mathbf{z}$ Fragment & Formula \\
\hline 1 & Kushenol F & 425.1954 & 9.88 & 425,465 & $\mathrm{C}_{25} \mathrm{H}_{28} \mathrm{O}_{6}$ \\
2 & 8-epi-Helenalin & 263.1281 & 10.04 & 263,507 & $\mathrm{C}_{15} \mathrm{H}_{18} \mathrm{O}_{4}$ \\
3 & $(-)$-Sesamin & 355.1176 & 10.75 & 355,453 & $\mathrm{C}_{20} \mathrm{H}_{18} \mathrm{O}_{6}$ \\
4 & Curcumin & 369.1326 & 11.04 & 369,423 & $\mathrm{C}_{21} \mathrm{H}_{20} \mathrm{O}_{6}$ \\
5 & Curcumin & 391.1149 & 11.04 & 369,437 & $\mathrm{C}_{21} \mathrm{H}_{20} \mathrm{O}_{6}$ \\
\hline
\end{tabular}

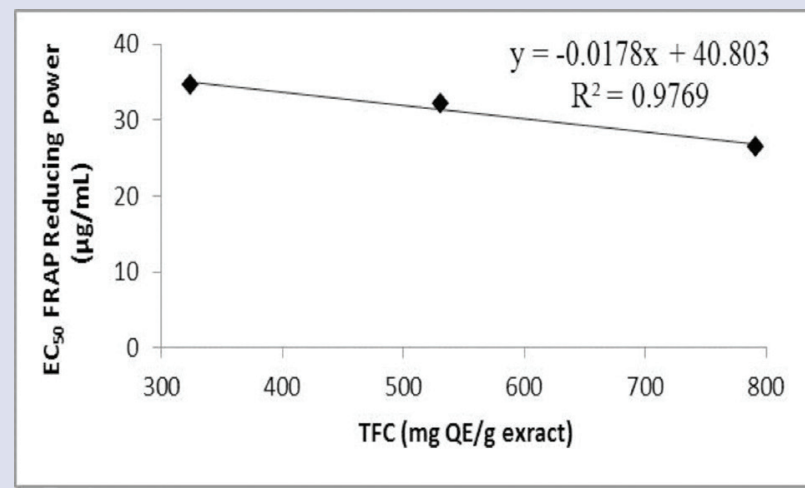

Figure 5: Regression Equation between TFC and antioxidant capacity by FRAP assay.

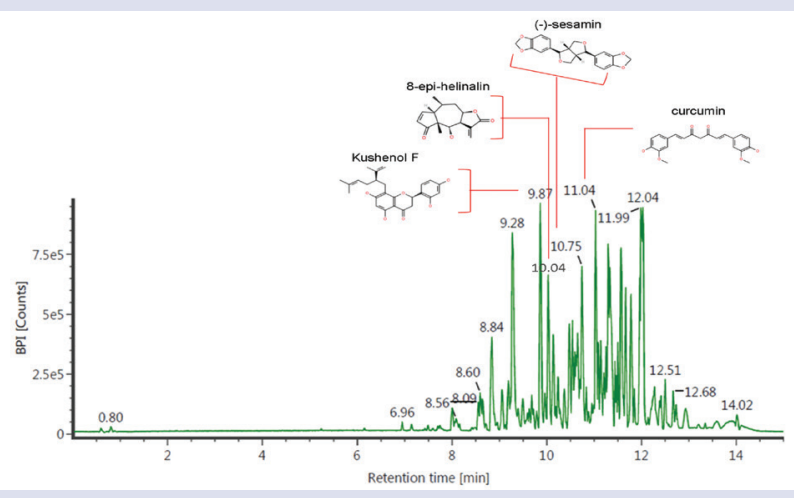

Figure 7: UPLC TOF MSE (100-1200) 6eV ESI+ - Low CE (BPI) Profile of Rough Propolis.

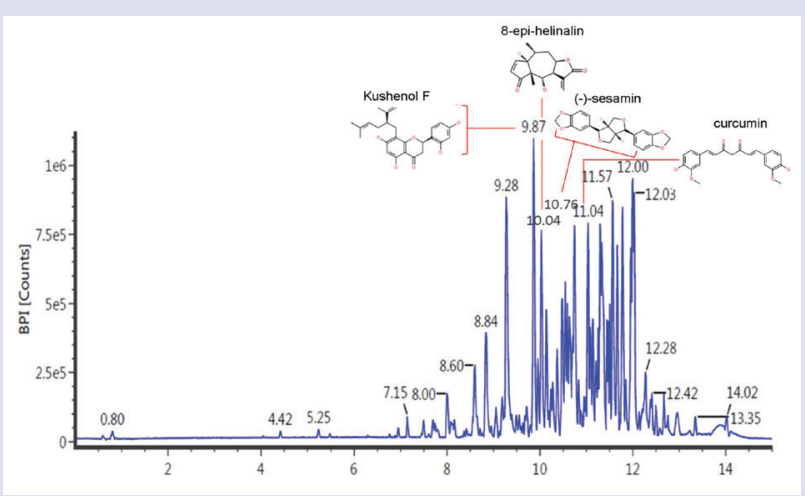

Figure 6: UPLC TOF MSE (100-1200) 6eV ESI+ - Low CE (BPI) Profile of Smooth Propolis. reported by Nélida Nina $(2016)^{17}$ ranged from $43.0 \pm 0.3$ to $176.0 \pm 4.8$ mg GAE g ${ }^{-1}$, and Brazilian Propolis those reported by Mara L F Bittencourt $(2015)^{22}$ ranged from $31.88 \pm 0.61$ to $204.30 \pm 3.80 \mathrm{mg} \mathrm{GAE} \mathrm{g}^{-1}$ of dry weight. But the results of TPC are inferior to Propolis Stingless Bees (Meliponinae) those reported by Karuane Saturnino $(2016)^{4}$ ranged from $620.01 \pm 6.45$ to $631.29 \pm 4.22 \mathrm{mg} \mathrm{GAE} \mathrm{g}^{-1}$ and Argentina Propolis those reported by Ana Lilia Salas $(2016)^{23}$ ranged from $587 \pm 20$ to 593 $\pm 15 \mathrm{mg} \mathrm{GAE} / \mathrm{g}$.

The results of TFC are superior to Algerian Propolis those reported by Zina Mouhoubi Tafinine $(2016)^{20}$ ranged from 1.25 to $49.46 \mathrm{mg}$ QE g ${ }^{-1}$, Chinese Propolis those reported by Kai Wang (2014) ${ }^{21}$ ranged from $124.92+79.74$ to $126.23+78.46 \mathrm{mg} \mathrm{QE} \mathrm{g}^{-1}$, Argentina Propolis those reported by Ana Lilia Salas (2016) ${ }^{23}$ ranged from $165 \pm 12$ to 185 $\pm 15 \mathrm{mg} \mathrm{QE}^{-1}$, and Bolivian Propolis those reported by Nélida Nina $(2016){ }^{17}$ ranged from $5.5 \pm 0.6$ to $57.1 \pm 2.8 \mathrm{mg} \mathrm{QE} \mathrm{g}^{-1}$. Overall, the total flavonoid contents of propolis ethanol extract from Tetragonula sp South Sulawesi Indonesia are significantly superior to another country. Flavo- 
noids, one of the secondary metabolites belongs to a polyphenolic class, are commonly found in different parts of the plant sources, propolis and honey. $^{24}$

The strongest antioxidant activities (lower $\mathrm{EC}_{50}$ ) were found in SPEE, $25.54 \mu \mathrm{g} / \mathrm{mL}$. SPEE samples, with highest TPC and TFC were also the high active towards $\mathrm{DPPH}$, with values ranging of regression equation between TPC and TFC with AA by DPPH assay was $\mathrm{Y}=-0.2465 \mathrm{X}+$ $125.85 ; \mathrm{R}^{2}=0.6776$, and $\mathrm{Y}=-0.0921 \mathrm{X}+92.948 ; \mathrm{R}^{2}=0.8009$, respectively. The DPPH assay is based on the reaction of the DPPH radical with the hydrogen-donors molecules from PEE. Phytochemical content in PEE inhibits the oxidation of other molecules, provided depends on its concentration, and reactivity towards the reactive oxygen species. A lower $\mathrm{EC}_{50}$ correlate better with higher $\mathrm{DPPH}$ radical scavenging activity, which represents the concentration of the extract to decrease $50 \%$ of the DPPH solution initial absorbance. Antioxidant potency is usually associated with the content of phenolic compounds due to their extensive conjugated $\pi$-electron systems that facilitate the donation of electrons from the hydroxyl moieties to oxidizingradical species. ${ }^{22}$

From the calculation data, it is known that PEE from this research are strong antioxidant, according to Jun et al. (2003), ${ }^{25}$ that classification of antioxidant power are strong antioxidant with strength level $\left(\mathrm{IC}_{50}<50\right.$ ppm), active ( $\left.\mathrm{IC}_{50} 50-100 \mathrm{ppm}\right)$, moderate $\left(\mathrm{IC}_{50} 101-250 \mathrm{ppm}\right)$, weak $\left(\mathrm{IC}_{50} 250-500 \mathrm{ppm}\right)$, and inactive $\left(\mathrm{IC}_{50}>500 \mathrm{ppm}\right) .{ }^{25} \mathrm{The}^{\mathrm{EC}} \mathrm{C}_{50} \mathrm{DPPH}$ radical scavenging activity of Propolis in this research are inferior to Bolivian Propolis those reported by Nélida Nina (2016) ${ }^{17}$ ranged from 4.54 to $48.27 \mu \mathrm{g} / \mathrm{mL}$, Propolis Stingless Bees (Meliponinae) those reported by Karuane Saturnino $(2016)^{4}$ ranged from $29.81 \pm 2.49$ to $50.23 \pm 1.60 \mu \mathrm{g} / \mathrm{mL}$ and Chinese Propolis those reported by Kai Wang $(2014)^{21}$ ranged from $15.49 \pm 70.59$ to $28.69 \pm 71.52 \mu \mathrm{g} / \mathrm{mL}$, but it superior to the Brazilian Propolis those reported by Mara L F Bittencourt $(2015)^{22}$ ranged from 21.50 to $78.77 \mu \mathrm{g} / \mathrm{mL}$.

The reducing power of FRAP capacity obtained from PEE related with a lower $\mathrm{EC}_{50}$, the concentration to reduce $50 \%$ of the FRAP reagent initial absorbance. The reducing power obtained for the rough propolis ethanolic extract (RPEE), PEE from rough propolis, are the lowest than the other types of propolis sample. SPEE samples gave the best reducing power. The $\mathrm{EC}_{50}$ reducing power capacity of PEE was inferior to Garcinia porrecta Laness extract those reported by Shinta Marlin $(2017)^{16}$ ranged from 1.33 to $19.96 \mu \mathrm{g} / \mathrm{mL}$.

The antioxidant capacity of the PEE was determined using the FRAP method, based on the reduction of potassium ferricyanide. The reducing agents in the PEE induced reduction of the ferric ions $\left(\mathrm{Fe}^{+3}\right)$ to ferrous ion $\left(\mathrm{Fe}^{+2}\right)$. Ion $\mathrm{Fe}^{+3}$ chelated with nucleophilic aromatic rings as specific chelators groups present in the polyphenolic compound. An increase in absorbance indicates a high reducing power. ${ }^{20}$ The reducing power capacity of the samples is probably due to the phytochemical components present in propolis extracts.

Tetragonula spp produces propolis that has large quantities of total flavonoid and phenolic compounds compared to other types of bees. ${ }^{26}$ Propolis have the highest antioxidant activity compare than other bee product. $^{20}$

HPLC-ESI-MS/MS analysis used to identify the primary compounds of PEE was carried out comparing the Rt, molecular weight and MS fragmentation patterns with UNIFI literature database. As shown in Figure 6, a total of 11 compounds were identified in smooth propolis extract, and the results were shown in Table 6. As shown in Figure 7, a total of 9 compounds were identified in rough propolis extract, and the results were shown in Table 7. The results of the LC-MS analysis provide major peaks determining the presence of phytochemical compounds, of Kushenol-F, 8-epi-Helenalin, (-)-Sesamin, and Curcumin, but various com- pounds were not identified in UNIFI database, or previous research has studied chemical compound in Propolis. Tetragonula bees gather propolis from diverse resinous plant parts, and in different phytogeographic regions, its chemical composition might vary significantly. ${ }^{3}$

Curcumin, 8-epi-Helenalin, (-)-Sesamin, and Kushenol-F, were found in propolis extract have antioxidant activity. Curcumin, from genus Zingiberaceae, has a unique conjugated structure shows a typical radical trapping ability as a chain-breaking antioxidant, including two methoxylated phenols and an enol form of $\beta$-diketone. ${ }^{27}$ Helenalin was an antioxidant potential, while widely considered not to be an attribute of sesquiterpene lactone due to their structure. ${ }^{28}$ The presence of phenylpropanoid compound namely lignan such as sesamin provide adefense mechanism against reactive oxygen species. ${ }^{29}$ Kushenol-F, a flavonoid compound, also indicate the complex antioxidant activity.

The content of 8-epi-helenalin compounds in this research, was the first reported to be found in propolis. While sesamin has been reported by Bankova V (2000) contained in Propolis of the Canary Islands.1 Then the content of curcumin in propolis has been reported by Li Yang (2013) who examines Chinese propolis.30 Then the compound kushenol $\mathrm{F}$ has been reported to be present in Libyan propolis by Siheri et al (2016). ${ }^{31}$

\section{CONCLUSION}

Smooth propolis which taken from inside the nest was the most potent antioxidant among of all the types of examined propolis. The antioxidant activity was influenced by the phenolic content of.

\section{ACKNOWLEDGEMENT}

The author would like to thank the financial support from DRPM UI Grant of Indexed International Publication of Student Final Project (Publikasi International Terindeks Untuk Tugas Akhir Mahasiswa/ PITTA) 2017.

\section{CONFLICT OF INTEREST}

We have no conflicts of interest to disclose and we hereby transfer, assign, or otherwise convey all copyright ownership, including all rights incidental thereto, exclusively to the journal, in the event that such work is published by the journal.

\section{ABBREVIATIONS USED}

PEE: Propolis Ethanolic Extracts; FRAP: Ferric Reducing Antioxidant Power; UPLC-TOF-MS: Ultra Performance Liquid Chromatography TOF Mass Spectrometer; $\mathbf{E C}_{50}$ : The concentration of samples resulting in 50\% antioxidant capacity; DPPH:2,2-Diphenyl- 1-picrylhydrazyl; TPTZ:2,4,6-Tri(2-pyridyl)-s-triazine; TPC:Total Phenolic Content; TFC: Total Flavonoid Content; GAE: Gallic Acid Equivalents; QE : Quercetin Equivalents; AA: Antioxidant Activity; MPEE: Mix Propolis Ethanolic Extract; SPEE: Smooth Propolis Ethanolic Extract; RPEE: Rough Propolis Ethanolic Extract (RPEE).

\section{REFERENCES}

1. Bankova V, Castro S De, Marcucci M. Propolis : Recent advances in chemistry and plant origin. Apidologie. 2000;31(1):3-15. doi:10.1051/apido:2000102

2. Groot AC. Propolis: A review of properties, applications, chemical composition, contact allergy, and other adverse effects. Am Contact Dermat Soc. 2013; 24(6):263-82. doi:10.1097/DER.0000000000000011.

3. Popova M, Dimitrova R, Al-Lawati HT, Tsvetkova I, Najdenski H, Bankova V. Omani propolis: chemical profiling, antibacterial activity and new propolis plant sources. Chem Cent J. 2013;7(1):158. doi:10.1186/1752-153X-7-158.

4. Araujo KS, Santos-Jr JF, Otake-Sato M, et al. Physicochemical properties and antioxidant capacity of propolis stingless bees (Meliponinae) and Apisfrom two so regions of Tocantins, Brazil. Acta Amaz. 2016;46(1):61-8. doi:10.1590/18094392201501045 
5. Bankova V. Chemical diversity of propolis and the problem of standardization. J Ethnopharmacol. 2005;100(1-2):114-7. doi:10.1016/j.jep.2005.05.004.

6. Suriawanto N. Nesting sites characteristics of stingless bees (Hymenoptera: Apidae) in Central Sulawesi, Indonesia. J Insect Biodivers. 2017;5(10):1-9. doi:10.12976/jib/2017.5.10.

7. Mahani, Nurhadi B, Subroto E, Herudiyanto M. Bee Propolis Trigona spp Potential and Uniqueness in Indonesia. In: Proceeding University Malaysia Terengganu Annual Sciences 2011. Trengganu, Malaysia; 2011.

8. Nakajima Y, Tsuruma K, Shimazawa M, Mishima S, Hara H. Comparison of bee products based on assays of antioxidant capacities. Bio Med Central Complement Altern Med. 2009;9(1):4. doi:10.1186/1472-6882-9-4

9. Sahlan M, Supardi T. Encapsulation of indonesian propolis by Casein micelle. Int J Pharma Bio Sci. 2013;4(1):297-305.

10. Departemen Kesehatan Republik Indonesia. Materia Medika Indonesia Jilid VI. Jakarta: Departemen Kesehatan Republik Indonesia; 1995

11. Harborne AJ. Phytochemical Methods a Guide to Modern Techniques of Plant Analysis. 3rd ed. Springer Netherlands; 1998.

12. Ahmad I, Yanuar A, Mulia K, Mun'im A. Application of Ionic Liquid as a Green Solvent for Polyphenolics Content Extraction of Peperomia pellucida (L) Kunth Herb. J Young Pharm. 2017;9(4):486-90. doi:10.5530/jyp.2017.

13. Farasat M, Khavari-Nejad R. Antioxidant Activity, Total Phenolics and Flavonoid Contents of some Edible Green Seaweeds from Northern Coasts of the Persian Gulf. Iran J Pharm Res IJPR. 2014;13(1):163-70.

14. Bobo-García G, Davidov-Pardo G, Arroqui C, Vírseda P, Marín-Arroyo MR, Navarro M. Intra-laboratory validation of microplate methods for total phenolic content and antioxidant activity on polyphenolic extracts, and comparison with conventional spectrophotometric methods. J Sci Food Agric. 2015;95(1):204-9. doi:10.1002/jsfa.6706.

15. Bolanos-De LTAAS, Henderson T, Nigam PS, Owusu-Apenten RK. A universally calibrated microplate ferric reducing antioxidant power (FRAP) assay for foods and applications to Manuka honey. Food Chem. 2015;174:119-23. doi:10.1016/j. foodchem. 2014.11.009.

16. Marlin S, Elya B. Antioxidant Activity and Lipoxygenase Enzyme Inhibition Assay with Total Flavonoid Content from Garcinia hombroniana Pierre Leaves. Pharmacogn J. 2017;9(2):257-66. doi:10.5530/pj.2017.2.45.

17. Nina N, Quispe C, Jimenez-Aspee F, Theoduloz C, Gimenez A, SchmedaHirschmann G. Chemical profiling and antioxidant activity of Bolivian propolis. J Sci Food Agric. 2016;96(6):2142-53. doi:10.1002/jsfa.7330.

18. Kustiawan PM, Puthong S, Arung ET, Chanchao C. In vitro cytotoxicity of Indonesian stingless bee products against human cancer cell lines. Asian Pac J Trop Biomed. 2014;4(7):549-56. doi:10.12980/APJTB.4.2014APJTB2013-0039.

19. Hasan AEZ, Mangunwidjaja D, Sunarti TC, Suparno O, Setiyono A. Investigat- ing the antioxidant and anticytotoxic activities of propolis collected from five regions of Indonesia and their abilities to induce apoptosis. Emirates J Food Agric. 2014;26(5):390-8. doi:10.9755/ejfa.v26i5.16549

20. Mouhoubi-Tafinine Z, Ouchemoukh S, Tamendjari A. Antioxidant activity of some Algerian honey and propolis. Ind Crops Prod. 2016;88:85-90. doi:10.1016/j. indcrop.2016.02.033.

21. Wang K, Zhang J, Ping S, et al. Anti-inflammatory effects of ethanol extracts of Chinese propolis and buds from poplar (Populus $\times$ canadensis). J Ethnopharmacol. 2014;155(1):300-11. doi:10.1016/j.jep.2014.05.037.

22. Bittencourt MLF, Ribeiro PR, Franco RLP, Hilhorst HWM, Castro RD, Fernandez LG. Metabolite profiling, antioxidant and antibacterial activities of Brazilian propolis: Use of correlation and multivariate analyses to identify potential bioactive compounds. Food Res Int. 2015;76(3):449-57. doi:10.1016/j. foodres.2015.07.008.

23. Salas AL, Alberto MR, Zampini IC, et al. Biological activities of polyphenolsenriched propolis from Argentina arid regions. Phytomedicine. 2016;23(1):27 31. doi:10.1016/j.phymed. 2015.11.007.

24. Venu Gopal J. Morin Hydrate: Botanical origin, pharmacological activity and its applications: A mini-review. Pharmacogn J. 2013;5(3):123-6. doi:10.1016/j. phcgj.2013.04.006.

25. Jun M, Fu HY, Hong J, Wan X, Yang CS, Ho CT. Comparison of Antioxidant Activities of Isoflavones from Kudzu Root (Pueraria lobata Ohwi). J Food Sci. 2003;68(6):2117-22. doi:10.1111/j.1365-2621.2003.tb07029.x.

26. Dos-Santos PA, Bicalho B, De-Aquino NFR. Comparison of propolis from Apis mellifera and Tetragonisca angustula. Apidologie. 2003;34(3):291-8. doi:10.1051/ apido.

27. Nurrochmad A. REVIEW: The new paradigm of curcumin and its anticancer activity. Rumphius J Nat Prod Biochem. 2004;2(2):75-80. https://smujo.id/rinpb/ article/view/1423\%3E.

28. Zheleva-Dimitrova D, Balabanova V, Gevrenova R, Doichinova I, Vitkova A Chemometrics-based Approach in Analysis of Arnicae Flos. Pharmacogn Mag. 2015;11(44):S538. doi:10.4103/0973-1296.172958

29. Pathak N, Rai AK, Kumari R, Bhat KV. Value addition in sesame: A perspective on bioactive components for enhancing utility and profitability. Pharmacogn Rev. 2014;8(16):147-55. doi:10.4103/0973-7847.134249.

30. Yang L, Yan Q, Ma J, Wang Q, Zhang J. High Performance Liquid Chromatographic Determination of Phenolic Compounds in Propolis. Tropical Journal of Pharmaceutical Research. 2013;771-6. http://doi.org/10.4314/tjpr.v12i5.17

31. Siheri W, Zhang T, Ebiloma GU, Biddau M, Woods N, Hussain MY, et al. Chemical and Antimicrobial Profiling of Propolis from Different Regions within Libya. PLoS ONE. 2016;11(5):1-16. http://doi.org/10.1371/journal.pone.0155355

\section{GRAPHICAL ABSTRACT}

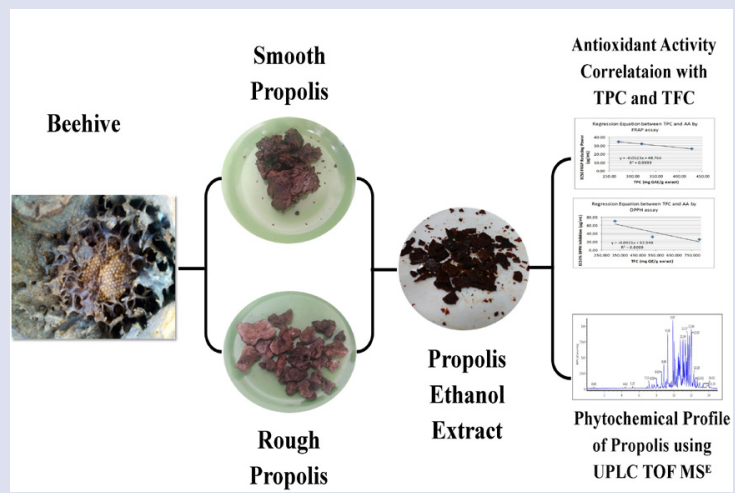

\section{SUMMARY}

- Tetragonula Bees produce propolis that contained one of the biological activity as an antioxidant, which is the most potent antioxidant of all the bee products.

- The types of beehive were smooth (taken from inside the nest), rough (taken from outside the hive) and mix (a combination of both). Smooth propolis was the most potent antioxidant among of all the types of examined propolis.

- The antioxidant activity was influenced by the polyphenol content of.

- This research was the first study reported polyphenol compound 8-epi-helenalin found in propolis

\section{ABOUT AUTHORS}

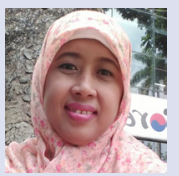

Diah Kartika Pratami, S.Si, Apt Master student at Biology Pharmacy, Faculty of Pharmacy, Universitas Indonesia. Her focus research on natural products extraction, microencapsulation, spray-drying, and antioxidant assays.

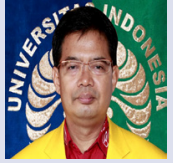

Dr. Abdul Mun'im, M.Si. Apt: Ph.D., Associate Professor at Department of Pharmacognosy-Phytochemistry, Faculty of Pharmacy, Universitas Indonesia. He has experience in the area of Pharmacognosy and Phytochemistry, working in drug discovery, extraction technology, Metabolite profiling, Structure Elucidation, and Degenerative Diseases (such as diabetes mellitus, hypertension, and cholesterol). 
Andini Sundowo M.Si: Master of Science, Researcher at Natural Product and Pharmaceutical Chemistry Research Group, Research Center for Chemistry, Indonesian Institute of Sciences. She has expertise in isolation of natural product, operations and data analysis of UPLC QTOF MS.

Dr. Muhamad Sahlan, S.Si., M. Eng: Dr, Assistant Professor at Research Center for Biomedical Engineering, Faculty of Engineering, Universitas Indonesia. He has experience in the area of Bioprocess engineering and Natural Products, working in drug discovery, delivery, and development of Honey Bees products, Bioprocess technology, and Product design.

Cite this article: Pratami DK, Mun'im A, Sahlan M, Sundowo A. Phytochemical Profile and Antioxidant Activity of Propolis Ethanolic Extract from Tetragonula Bee. Pharmacog J. 2018;10(1):128-35. 